\title{
Purification, characterization, and bioassay of putative protease inhibitors from Hevea brasiliensis latex
}

\author{
Purifikasi, karakterisasi, dan bioassay protease inhibitor putatif dari lateks tanaman karet (Hevea brasiliensis) \\ Riza Arief PUTRANTO ${ }^{1 *}$, SISWANTO $^{1)}$, Agustin Sri MULYATNI ${ }^{1)}$, Asmini BUDIANI ${ }^{1)}$ \& Radite \\ TISTAMA $^{2)}$ \\ 1) Indonesian Research Institute for Biotechnology and Bioindustry, Jl. Taman Kencana No. 1, Bogor 16128, Indonesia \\ ${ }^{2)}$ Sungei Putih Research Centre, Indonesian Rubber Research Institute, Kotak Pos 1415, Medan 20001, Indonesia
}

Diterima tgl 7 September 2016/ disetujui tgl 23 Desember 2016

\begin{abstract}
Abstrak
Lateks yang menyerupai cairan susu putih diperoleh dari penyadapan kulit batang tanaman karet (Hevea brasiliensis). Lateks merupakan sitoplasma dari jaringan pembuluh bernama latisifer yang didalamnya terkandung berbagai macam komponen, termasuk protein-protein penting. Berbagai jenis enzim yang memiliki fungsi terkait pertahanan tanaman dari serangan patogen dan pelukaan telah berhasil dideteksi di dalam lateks, di antaranya protease inhibitor (PI). Protease inhibitor memiliki aktivitas senyawa antifungi sehingga berpotensi untuk dimanfaatkan sebagai biofungisida. Pada penelitian ini, protease inhibitor putatif yang berasal dari serum B (lutoid) lateks tanaman karet telah berhasil diisolasi menggunakan teknik Ion Exchange Chroma-tography. Dari total 70 fraksi protein yang diekstrak dari kolom, hanya 26 fraksi yang menunjukkan kadar protein yang terukur. Kandungan protease inhibitor putatif yang di-peroleh berkisar antara 0,0067 hingga 0,022 $\mathrm{mL} / \mathrm{g}$ serum $B$ dari hasil 3 fraksi terpilih. Aktivitas penghambatan terhadap empat enzim protease (subtilisin A, tripsin, $\alpha$-kimotripsin, dan papain) menunjukkan karakteristik protease inhibitor putatif tersebut sebagai serine dan/atau cysteine inhibitor protease dengan persentase hambatan di atas 15\% terhadap protease target. Hasil SDS-PAGE memperlihatkan pemisahan protein dominan yang diperkirakan merupakan protease inhibitor putatif dengan berat molekul sebesar 21,5 kDa. Uji bioassay aktivitas antifungi secara in vitro dari protease inhibitor memperlihatkan penghambatan pertumbuhan miselium dari fungi Ganoderma
\end{abstract}

*Corresponding author: rizaputranto@iribb.org boninense, Sclerotium sp., dan Rigidosporus lignosus.

[Kata kunci : protease inhibitor, Hevea brasiliensis, lateks, serum B, ion exchange chromatography]

\begin{abstract}
Latex, a milky white liquid, is the main product from rubber tree (Hevea brasiliensis). Latex is the cytoplasm of complex cellular networks named laticifers in which it contains many different components, including important proteins. Various types of enzymes carrying functions associated with plant defense against pathogen and wounding have been detected in latex in which one of these enzymes is protease inhibitor (PI). Plant protease inhibitor has tremendous potential as an antifungal agent which can be developed as biofungicide. In this work, protease inhibitors from B-serum (lutoid) of rubber tree latex were isolated and purified using Ion Exchange Chromatography (IEC) technique. Of the total 70 fractions of proteins extracted from the columns, only 26 fractions showed measurable levels of protein. The concentration of obtained putative protease inhibitors (three fractions of IEC) ranged from 0.007 to $0.022 \mathrm{~mL} / \mathrm{g}$ B-serum. Inhibitory activity against four protease enzymes (subtilisin A, trypsin, $\alpha$-chymotrypsin, and papain) showed the characteristics of Hevea putative protease inhibitors from B-serum as serine and/or cysteine protease inhibitors with more than $15 \%$ inhibitory activity of target protease. Based on SDS-PAGE visualization, the molecular weight of dominant protein considered as Hevea putative protease inhibitors was $21.5 \mathrm{kDa}$. In vitro bioassay test of antifungal activity for Hevea putative
\end{abstract}


protease inhibitors showed reduced mycelium growth of Ganoderma boninense, Sclerotium sp., and Rigidosporus lignosus.

[Keywords: protease inhibitor, Hevea brasiliensis, latex, B-serum, ion exchange chromatography]

\section{Introduction}

To date, $H$. brasiliensis, also known as the rubber tree is the sole commercial source of natural rubber. The growth of rubber tree, originated from the Amazon jungle in Brazil, can reach a height of 30-40 $\mathrm{m}$ (Clément-Demange et al., 2007). Indonesia is the second largest natural rubber producer in the world after Thailand with a production of 3.2 million tons from 3.6 million hectares of rubber plantations in 2015. Indonesia supplies around $32 \%$ of the world's natural rubber production. Indonesian rubber plantation is largely owned by smallholders involving more than 10 million farmers (Soependi \& Arianto, 2014). Natural rubber particles are contained inside milky white liquid called latex. Latex is obtained by tapping generally every 2-3 days upon the bark of rubber tree. Latex is the cytoplasm of complex cellular network called laticifer containing rubber particles (de Faÿ \& Jacob, 1989). Latex separation using ultracentrifugation at 59,000 $\mathrm{g}$ revealed main characteristic components consisting of white fraction (rubber particles), orange or yellow fractions (Frey-Wyssling complex), colorless fraction (cytosolic serum or serum C) and lutoid containing-yellow grayish fraction at bottom (lutoidic serum or B-serum) (Moir, 1959).

Various type of proteins have been detected in latex fractions in which they have associated functions in plant defense against pathogens and wounding responses (Martin, 1991; Jacob et al., 1993, Aoki et al., 2014). In matter of fact, twentyfive percent of the proteins in $\mathrm{C}$ - and B-serums are known as antimicrobial agents in $H$. brasiliensis. Most of these proteins have the activity of chitinase/lysozyme which can degrade fungal and bacterial cell wall components such as chitin and peptidoglycan, respectively (Martin, 1991; Kanokwiroon et al., 2008). Other lutoid-contained proteins such as chitinase, glucanase, hevein, hevamine have antifungal activity against Botrytis cinerea, Fusarium culmorum, Fusarium oxysporum, Phycomyces blakesleeanus, and Trichoderma hamatum (Bokma et al., 2000; Churngchow et al., 1995, Chye \& Cheung, 1995, Parijs et al., 1991). By contrast, protease inhibitor was less studied in comparison to other proteins in $H$. brasiliensis.

Plant protease inhibitors (PI) are small proteins ranging from $8-20 \mathrm{kDa}$, commonly accumulated as $10 \%$ of the total protein content in seed and storage tissues (Malolo et al., 2015). The activity of protease inhibitor is related to their ability to form stable complex targeting proteases in order to inhibit, alter or prevent access to the active site of the enzyme so that the protein hydrolysis does not occur (Ryan, 1990; van der Hoorn, 2008; Farady \& Craik, 2010). The protease inhibitor was structured by high content of cysteine residues forming disulfide bonds to withstand high temperature, extreme $\mathrm{pH}$ or proteolysis (Howe \& Jander, 2008; Kim et al., 2009). Typically, the inhibitors are divided by at least 13 families or types such as Serpin (Serine PI), Bowman Birk inhibitors (BBIs), Squash inhibitors, Kunitz, Cereal trypsin/ $\alpha$-amylase inhibitors, Mustard (Sinapis) trypsin inhibitor (MSI), Potato type I PIs (PI1), Potato type II PIs (PI2), Cysteine PIs (CYS), Family-1 cystatins (stefin family), Family-2 cystatins (cystatin family), Family-3 cystatins (kininogen family), Family-4 cystatins (phytocystatins), and Aspartyl and metallocarboxypeptidase inhibitors (Habib \& Fazili, 2007). Protease inhibitors are generally involved in defense mechanisms against biotic stress and developmental aspects (Chisholm et al., 2006; BoexFontvieille et al., 2015; Habib \& Fazili, 2007; Shan et al., 2008; Steppuhn \& Baldwin, 2007). Recently, the involvement of plant protease inhibitors under abiotic stress was also acknowledged (Shan et al., 2008; Zhang et al., 2008).

The increased use in agriculture sector as an antimicrobial agent has positioned plant protease inhibitors as an important product (Bijina et al., 2011; Islamov et al., 2012; Sack et al., 2015). Isolation and characterization of protease inhibitors from various plant species have been carried out using affinity column chromatography (Bijina et al., 2011; Popovic et al., 2013; Al-Assadi, 2013, Bunyatang et al., 2013; Chaudhary et al., 2008; Sabotič et al., 2012). In H. brasiliensis, several types of protease inhibitors have also been successfully extracted from latex 
(Bangrak \& Chotigeat, 2011; Kanokwiroon et al., 2008; Sritanyarat et al., 2006). Bunyatang et al. (2013) has demonstrated the inhibitory activity of Hevea protease inhibitors against the mycelium growth of Phytophthora palmivora.

The objective of this study was to purify and characterize putative protease inhibitors extracted from B-serum latex of Hevea brasiliensis. Ion exchange column chromatography technique was used to separate pure protein fraction of different protease inhibitors. SDS-PAGE visualization has been used to characterize putative protease inhibitors. Inhibitory activity against four protease enzymes (subtilisin A, trypsin, $\alpha$-chymotrypsin, and papain) showed the characteristics of Hevea putative protease inhibitors from B-serum latex. A bioassay test of Hevea putative protease inhibitors has confirmed its antifungal activity against Ganoderma boninense, Sclerotium sp., and Rigidosporus lignosus.

\section{Material and Methods}

\section{Plant material and preparation of latex sample}

Latex was collected from 8-year-old mature trees of Hevea clone PB 260 at Ciomas Trial Station, Bogor, Indonesia (Latitude -6.60399; Longitude 106.78358). The tapping frequency of the clone PB 260 was once every 2 days with ethephon stimulation 12 times per year (d2 12/y). Latex was kept inside a sterile tube and stored on ice for 5 to 35 minutes after tapping. Latex samples was centrifugated at 25,000 $\mathrm{g}$ for 45 minutes to separate upper phase containing rubber particles, middle phase containing $\mathrm{C}$-serum (cytosolic serum) and bottom phase containing Bserum (lutoidic serum) (Figure 1). Pellet from bottom phase was gently crushed in a small volume of buffer solution $0.1 \mathrm{M}$ Tris- $\mathrm{HCl} \mathrm{pH} 7.2$ containing $1 \mathrm{mM} \mathrm{MgCl} 2,10 \%$ glycerol, $1 \mathrm{mM}$ EDTA, $1 \mathrm{mM} \beta$ mercaptoethanol. Subsequent centrifugation was carried out to obtain lutoidic serum (Siswanto, 2012).

Purification of protease inhibitor from latex using Ion Exchange Chromatography (IEC)

To obtain Hevea protease inhibitors, the B-serum latex was purified using protein purification techniques which include precipitation with ammonium sulfate followed by ion exchange chromatography (IEC) (Al-Assadi, 2013; Jungbauer
\& Hahn, 2009; Paiva et al., 2013). The concentration of protease inhibitor was carried out by separately adding various concentrations of ammonium sulphate $(30,60$, and $90 \%)$ into the crude extract to obtain a good comparison of saturated between precipitated and concentrated of protease inhibitor from latex fractions. A volume of $8 \mathrm{~mL}$ of concentrated extracts produced from ammonium sulphate precipitation with a saturation level of $60 \%$ was added in the ion exchange diethyl amino ethyl cellulose (DEAD-cellulose) column with dimensions of $3.5 \times 18 \mathrm{~cm}$. The column was then rinsed using $0.02 \mathrm{M}$ phosphate buffer $\mathrm{pH} 7.6$ with the gradual and linear additions of $0.1-1 \mathrm{M}$ sodium chloride at a flow rate of $30 \mathrm{~mL} /$ hour. A total of $3 \mathrm{~mL}$ solution per fraction from the column were collected. Each IEC fraction was spectrophotometrically measured at 280 $\mathrm{nm}$.

SDS preparative gel electrophoresis and gel staining

SDS-PAGE was carried out by following modified method (Siswanto, 2012). Latex fraction proteins were separated by mono-dimensional acrylamide SDS-PAGE (Biorad, USA) using 12\% $(\mathrm{w} / \mathrm{v})$ separating gels, $\mathrm{pH} 8.8$ and $4 \%(\mathrm{w} / \mathrm{v})$ stacking gel $\mathrm{pH}$ 6.8. Proteins of IEC fractions were diluted 1: $5(\mathrm{v} / \mathrm{v})$ in a sample buffer solution $(50 \mathrm{mM}$ Tris $\mathrm{HCl}$, $\mathrm{pH} \quad 6.8, \quad 2 \% \quad$ SDS, $10 \%$ glycerol, $0.0025 \%$ bromophenol blue and $2 \% \beta$-mercaptoethanol).

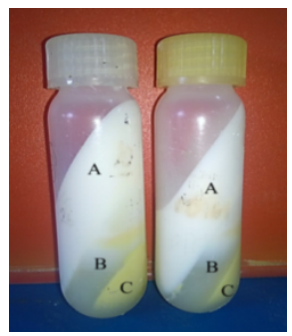

Figure 1. Profile of latex separation by centrifugation. The rotational speed was at $25,000 \mathrm{~g}$ for 45 minutes. The resulted separation were upper phase/rubber particles (A), middle phase/cytosolic C-serum (B), and bottom phase/lutoid/B-serum (C).

Gambar 1. Profil pemisahan lateks secara sentrifugasi. Kecepatan rotasi adalah $25.000 \mathrm{~g}$ selama 45 menit. Hasil pemisahan yang diperoleh adalah fase atas/partikel karet (A), fase tengah/serum $C$, (B), dan fase bawah/ lutoid/serum $B(C)$. 
The mixture was heated for 3 minutes at a temperature of $100^{\circ} \mathrm{C}$. A volume of $20 \mu \mathrm{L}$ of sample was electrophoresed in gel. The protein was detected using silver staining. The molecular weight of the protease inhibitor was estimated based on the MW of standard proteins.

After electrophoresis, the gel slab was fixed in $40 \%$ ethanol, $10 \%$ acetic acid, $50 \%$ ddH $2 \mathrm{O}$ for $1 \mathrm{~h}$ or in $5 \%$ ethanol, $5 \%$ acetic acid and $90 \% \mathrm{ddH}_{2}$ for overnight. The gel then was sensitized in $0.5 \mathrm{M}$ natrium acetate and $1 \%$ glutaraldehyde for 30 minutes, and rinsed with deionized water for $2 \times 5$ minutes. The gel was resensitized again with $0.05 \%$ (w/v) naphthalene disulphonic acid in $\mathrm{H}_{2} \mathrm{O}$ for 30 minutes, then rinsed with four changes of deionized water for 5 minutes each. After rinsing, the gel was submerged in $0.8 \%(\mathrm{w} / \mathrm{v})$ of silver nitrate diluted in silver reagent stock solution $(50 \mathrm{~mL}$ ammonia $25 \%$, $\left.850 \mathrm{~mL} \mathrm{H}_{2} \mathrm{O}, 80 \mathrm{~mL} \mathrm{NaOH} 1 \mathrm{~N}\right)$ for 30 minutes. The gel was rinsed twice with deionized water for 1 to 5 minutes, and then developed in $0.1 \%(\mathrm{v} / \mathrm{v})$ formaldehyde, $0.01 \%(\mathrm{w} / \mathrm{v}) \mathrm{Na}$-citrate solution for 1 to 5 minutes.

Specific activity of protease inhibitors against various protease enzymes

Inhibitory activity test of protease inhibitors against serine and cysteine type proteases was carried out by following modified protocol from Bunyatang et al. (2013). PI inhibitory activity on serine type proteases was assayed by monitoring the inhibition of trypsin, chymotrypsin, and subtilisin A, while the cysteine type proteases were tested with papain. The test was carried out using azocasein as substrate. B-serum and selected IEC fraction samples were preincubated with appropriate amount of enzyme as follows: subtilisin A $(0.9 \mu \mathrm{g})$, trypsin $(0.2$ $\mu \mathrm{g})$, chymotrypsin $(0.2 \mu \mathrm{g})$ dan papain $(2.5 \mu \mathrm{g})$ in order to obtain the same absorbance value before the inhibition of PI. The reaction mixtures were adjusted to $600 \mu \mathrm{L}$ final volume with $20 \mathrm{mM}$ Tris- $\mathrm{HCl}$ ( $\mathrm{pH}$ 7.0), and preincubated for 30 minutes at $37^{\circ} \mathrm{C}$. The reaction was stopped by adding $300 \mu \mathrm{L}$ of $10 \%(\mathrm{v} / \mathrm{v})$ trichloro-acetic acid (TCA), mixed and centrifuged at $11,000 \mathrm{~g}$ for 10 minutes. A total of $400 \mu \mathrm{L}$ obtained supernatant was mixed with $600 \mu \mathrm{L}$ of 0.5 $\mathrm{M} \mathrm{NaOH}$ and measured spectrophotometrically at $440 \mathrm{~nm}$. One protease unit was defined as the amount of enzyme that increased absorbance by $1 \mathrm{OD} / \mathrm{min}$ and one protease inhibitor unit is defined as the amount of protease inhibitor that inhibited one unit of protease activity. The protease inhibitor activity was expressed in terms of percent inhibition (Bijina et al., 2011). It was calculated using the following formula used by Musor et al. (2010): Percent inhibition $(\%)=\{[$ Abs protease enzyme $-($ Abs sample - Abs sample blank)]/Abs protease enzyme $\mathrm{x} 100 \%$. In this paper, the inhibition percentage below 5 was considered as low inhibition activity, whereas the value above $15 \%$ was considered as high inhibition activity. The values in between were considered as medium-high inhibition activity.

Bioassay of protease inhibitors for antifungal activity

Pathogenic fungi consisting of $G$. boninense, Sclerotium sp., and $R$. lignosus were obtained from the collection of Indonesian Research Institute for Biotechnology and Bioindustry, Bogor, Indonesia (Latitude -6.58862; Longitude106.80217) (Figure 2). The bioassay of fungal activity was performed using modified technique from Suryanto et al. (2012). The outer colony of pure fungal cultures were taken using a cork borer with a diameter of $1 \mathrm{~cm}$ and inoculated on potato dextrose agar (PDA) media. Non-diluted putative protein inhibitor resulted from IEC fraction $(100 \%)$ was dropped and spread in the surface of fungal growth media. The fungal cultures were incubated at room temperature for 4 days. The growth rate ratio is the difference between daily fungal colonization compared to untreated colonies as negative control. Commercial cocktail protease inhibitor P8340 (Sigma-Aldrich, USA) was used as positive control. The putative protease inhibitor antagonistic activity was characterized by the reduced growth of tested fungi. Observations were started from the first to fourth day in biological triplicates for each day and each fungus.

\section{Results and Discussion}

SDS-PAGE and gel staining of putative protease inhibitor from $\mathrm{H}$. brasiliensis latex

The Ion Exchange Chromatography (IEC) analysis has resulted 70 fractions from the column. SDS-PAGE electrophoresis was carried out on 26 of total 70 IEC fractions (Figure 3). These fraction 


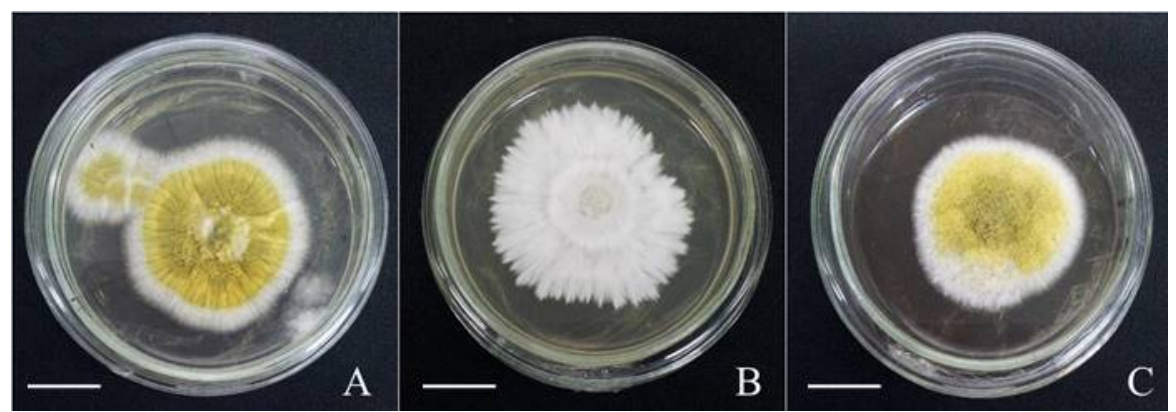

Figure 2. Visualization of G. boninense (A), Sclerotium sp. (B), and R. lignosus (C) for antifungal bioassay of H. brasiliensis putative protease inhibitors. These were the in vitro growth of fungi after 36 hours in PDA medium. The scale bar indicates $1.25 \mathrm{~cm}$.

Gambar 2. Penampakan visual G. boninense (A), Sclerotium sp. (B), and R. lignosus (C) untuk uji bioassay antifungi untuk protease inhibitor putatif dari $\mathrm{H}$. brasiliensis. Penampakan tersebut adalah pertumbuhan fungi secara in vitro setelah 36 jam dalam PDA medium. Skala bar menunjukkan jarak 1,25 cm.

were the purified B-serum proteins. The visualized bands were the abundant and dominant proteins existing in the IEC fraction. Based on literature, the molecular weight of protease inhibitors was expected at 8-20 $\mathrm{kDa}$. In this work, the molecular weight of the dominant was meashowed a $21.5 \mathrm{kDa}$ and could be expected as putative Hevea protease inhibitors. Further electrophoresis analysis using azocasein as a substrate could validate the putative protease inhibitor by visualizing the absence and presence of protein bands. Since azocasein is a protease, the absence of band in the electrophoresis gel would clarify that the dominant protein visualized in this work is Hevea protease inhibitor.

The purification of putative protease inhibitors from B-serum was expected to be achieved at higher fraction of IEC showing a single and thin protein band. Three IEC fractions $\left(3^{\text {rd }}, 19^{\text {th }}\right.$, and $\left.20^{\text {th }}\right)$ were selected for measurement of protein content showing concentration of $0.007,0.022$, and $0.015 \mathrm{~g}$ protein $/ \mathrm{mL}$ fraction, respectively (Figure 4 ). The $3^{\text {rd }}$ IEC fraction showed a lowest concentration of protein, while the $19^{\text {th }}$ fraction was highest. This result confirmed the PI obtained at $19^{\text {th }}$ was predicted to have higher pureness against early IEC fraction.

\section{Specificity of $\mathrm{H}$. brasiliensis putative protease inhibitors}

Using azocasein as a substrate, inhibitory activity of Hevea protease inhibitors against four protease enzymes (subtilisin $A$, trypsin, $\alpha$-chymotrypsin, and papain) were measured. The measurement can be used to determine the specific activity of protease inhibitor isolated from B-serum latex (Figure 5). Based on known PI concentration measured by Bradford assay, a volume of $20 \mu \mathrm{L}$ for each IEC fraction $\left(3^{\text {rd }}, 19^{\text {th }}\right.$, and $\left.20^{\text {th }}\right)$ was used for inhibitory assay counting in total $0.14,0.44$, and $3 \mathrm{mg}$ of putative $\mathrm{PI}$, respectively. The negative control $\left(\mathrm{H}_{2} \mathrm{O}\right)$ showed no inhibitory activity against protease enzymes as expected. Crude B-serum from latex was likewise measured its activity as a comparison. It showed inhibitory activity below 5\% against subtilisin A, trypsin, $\alpha$-chymotrypsin, and papain. The $3^{\text {rd }}$ IEC fraction inhibited 5 to $10 \%$ activity of subtilisin A and less than 5\% activities of trypsin, $\alpha$ chymotrypsin, and papain. Due to the type of subtilisin $\mathrm{A}$ as a serine-type protease, the specific activity predicted that the $3^{\text {rd }}$ fraction can be considered as serine-type protease inhibitor. The $19^{\text {th }}$ IEC fraction inhibited higher than $15 \%$ of papain's activity in comparison with $11-15 \%$ of $\alpha$ chymotrypsin's activity, $5-10 \%$ of trypsin's activity, and below $5 \%$ of subtilisin A's activity. Since papain is a cysteine-type protease, the specific inhibition against papain demonstrated that the $19^{\text {th }}$ fraction can be predominantly considered as cysteine-type protease inhibitor. The $20^{\text {th }}$ fraction had inhibitory activity below $5 \%$ against subtilisin $\mathrm{A}$, trypsin, and papain but higher than $5 \%$ for $\alpha$-chymotrypsin. The $\alpha$-chymotrypsin is a serine-type protease meaning that the $20^{\text {th }}$ fraction could be predicted as a serinetype protease inhibitor (Figure 5). 

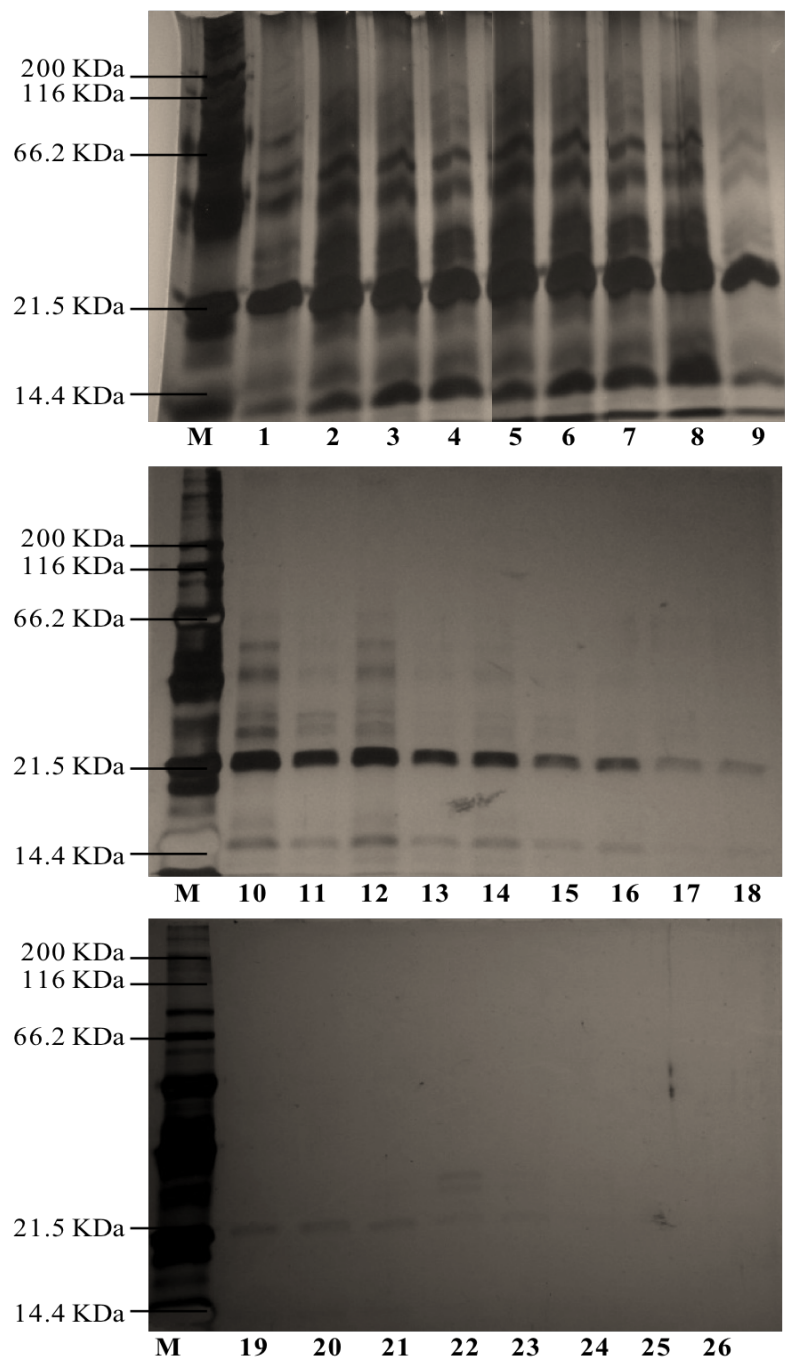

Figure 3. Profile of 26 Ion Exchange Chromatography (IEC) fractions on SDS-PAGE stained with silver nitrate. Proteins were separated on $12 \%$ polyacrylamide gel. M: molecular weight protein marker.

Gambar 3. Profil dari 26 fraksi protein hasil Ion Exchange Chromatography (IEC) pada SDS-PAGE yang diwarnai dengan perak nitrat. Protein dipisahkan pada gel poliakrilamid 12\%. M: marka berat molekul protein.

As a positive control, aprotinin is known as the small protein bovine pancreatic trypsin inhibitor (BPTI), an antifibrinolytic molecule that inhibits trypsin and related proteolytic enzymes (Zhirnov et al., 2011b). Aprotinin is a trypsin-type protease inhibitor (Zhirnov et al., 2011a). In this work, aprotinin and trypsin inhibitor showed an inhibition activity of $11 \%$ and higher than $15 \%$ against subtilisin A and trypsin, respectively. As expected, both positive controls confirmed that the measurement of inhibitory activity was accurate. Taken together, these results concluded that protease inhibitors extracted from B-serum latex were characterized as serine and/or cysteine-type protease inhibitors. In accordance with the literature, serine and cysteine protease inhibitors are two types found in large quantities in the cells (Habib \& Fazili, 2007; Mendoza-Blanco \& Casaretto, 2012; Popovic et al., 2013). Both of these PI are part of cell homeostasis playing a role in plant defense against pathogens (Hartl et al., 2011, Kim et al., 2009).

In the literature, Bunyatang et al. (2013) has demonstrated that a serine-type of HbPI inhibited almost $40 \%$ activity of subtilisin A using an activation of copper sulphate. Moreover, recombinant $\mathrm{HbPI}$ has shown multi-functional inhibition of subtilisin $\mathrm{A}$, trypsin, and $\alpha$-amylase with approximately 20,30 , and $65 \%$ of value, respectively (Bunyatang et al., 2016). In this work, 
the inhibition of proteases (subtilisin A, trypsin, and $\alpha$-chymotrypsin) against putative HbPI ranged between $5-15 \%$. Only $19^{\text {th }}$ IEC fraction exposed $30 \%$ of papain's inhibition resulting a clear evident of cysteine-type PI (data not shown). This result showed that the putative HbPIs obtained in this work are comparable to previous works by Bunyatang et al., (2013). Finally, the purity and concentration of $\mathrm{HbPI}$ are limiting factors to achieve clear inhibition of proteases. In the future perspective, a mutagenesis study could be proposed in order to confirm the inhibition activity of putative $\mathrm{HbPI}$

Bioassay of Hevea putative protease inhibitors for antifungal activity

Enzyme-inhibitor interactions, including protease inhibitors at the plant-pathogen interface are the early defense mechanism in cellular level (Misas-Villamil \& van der Hoorn, 2008). The measurement of antimicrobial activity serves as a simple model of these interactions. In this work, the antifungal activity of Hevea protease inhibitors (IEC fractions) was demonstrated by in vitro bioassay. Based on previous result, the $19^{\text {th }}$ IEC fraction was selected as an inhibitory agent. The fungus isolate was grown in PDA media containing different compositions of B-serum, $19^{\text {th }}$ IEC fraction, positive control (commercial cocktail protease inhibitor, known to be a serine-type protease inhibitor) and negative control $\left(\mathrm{H}_{2} \mathrm{O}\right)$. The tested fungi have been purified and characterized both visually and morphologically (data not shown). These fungi have been chosen in regard to their virulence as major actors of important plant diseases. The fungus $G$. boninense is the cause of devastating basal stem root disease in oil palm (Hushiarian et al., 2013). The fungus Sclerotium sp. is the main pathogen of root rot disease in H. brasiliensis (Omorusi, 2012). Meanwhile, the fungus $R$. lignosus causes important white root diseases in $H$. brasiliensis (Omorusi, 2012; Ogbebor et al., 2015).

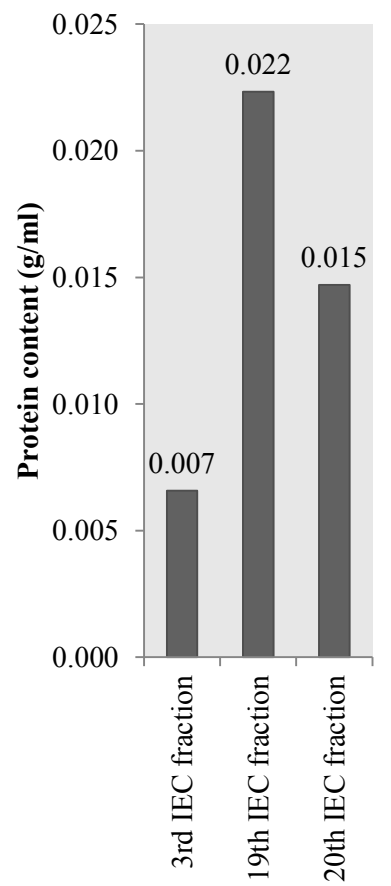

Figure 4. Protein concentration of three Ion Exchange Chromatography (IEC) fractions from Bserum latex after ammonium sulphate precipitation. The measurement was done using Bradford method with three biological replicates. The measurement was spectrophotometrically carried out at $440 \mathrm{~nm}$.

Gambar 4. Konsentrasi protein tiga fraksi Ion Exchange Chromatography (IEC) dari serum B lateks setelah presipitasi dengan ammonium sulfat. Pengukuran dilakukan menggunakan metode Bradford dengan tiga ulangan biologis. Pengukuran dilakukan secara spektrofotometeri pada absorbansi $440 \mathrm{~nm}$. 


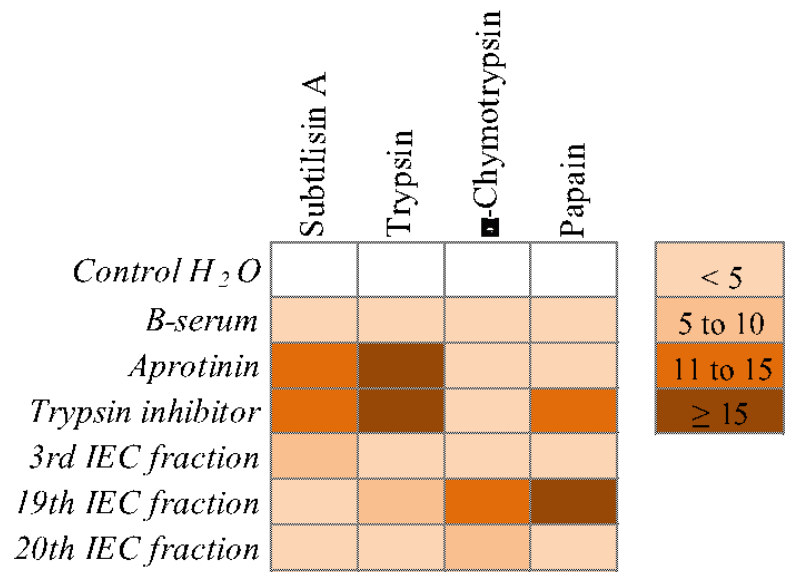

Figure 5. Specificity of protease inhibitors extracted from B-serum latex against four protease enzymes (subtilisin A, papain, trypsin, and $\alpha$-chymotrypsin) in $H$. brasiliensis. Aprotinin and trypsin inhibitor were used as positive controls. Values were mean of three biological replicates.

Gambar 5. Spesifisitas protease inhibitor yang diekstrak dari serum B lateks terhadap aktivitas empat enzim protease (subtilisin A, trypsin, dan a-chymotrypsin) in $\mathrm{H}$. brasiliensis. Aprotinin dan tripsin inhibitor digunakan sebagi kontrol positif. Nilai merupakan rerata dari tiga ulangan biologis.

The growth rate was determined by measuring the difference in diameter of petridishes between untreated and treated fungal colony for four consecutive days. This difference was considered as an indication of reduced fungal growth against inhibitory substances such as B-serum and IEC fraction. High differences in growth diameter reflected correspondingly the inhibition activity for each treatment. The data were then converted into percentage of inhibition. A volume of $5 \mu \mathrm{L}$ for $19^{\text {th }}$ IEC fraction was used counting $0.11 \mathrm{mg}$ of putative PI. In general, all three tested fungi showed progressively reduced growth from day- 1 to day- 4 under treatment of B-serum, $19^{\text {th }}$ IEC fraction, and positive control (commercial protease inhibitor) (Figure 6). In G. boninense, B-serum as well as $19^{\text {th }}$ IEC fraction and commercial protease inhibitor decelerated the fungal growth at day-4 with inhibition of $43.75,44.17$, and $43.65 \%$, respectively (Figure 6a). The IEC fraction showing similar inhibitory activity as the positive control confirmed their function as putative protease inhibitor. In Sclerotium sp., an obvious difference in growth diameter between treatments was spotted in day- 2 (Figure 6b). The IEC fraction showed higher inhibition of fungal growth $(10.42 \%)$ compared to Bserum $(5.83 \%)$. No differences in diameter were observed between the positive and negative controls for day-1 and day-2. At day-4, the fungal growth inhibition in B-serum, $19^{\text {th }}$ IEC fraction, and positive control were measured at 37.92, 42.92, and 39.58\%, respectively. In $R$. lignosus, all treatments showed identical profiles of inhibition activity (Figure 6c). The fungal growth inhibition at day-4 between three treatments was $46.25 \%$. Taken together; these results demonstrated generally the antifungal activity of Hevea putative protease inhibitors against three tested fungi. In regard to the inhibitory activity of $19^{\text {th }}$ IEC fraction and positive control, a serine-type protease inhibitor can be considered as an efficient agent to reduce the growth of $G$. boninense, Sclerotium sp., and $R$. lignosus.

Bunyatang et al. (2016) has demonstrated that $50 \%$ of Phytophthora palmivora's zoospore growth was inhibited after 3 days using $0.16 \mathrm{mg} / \mathrm{mL}$ of recombinant serine-type PI from $H$. brasiliensis. In previous experiment, a total inhibition of $P$. palmivora's mycelium growth after 6 days was acquired after a treatment of serine-type HbPI at a concentration of $5 \mu \mathrm{g} / \mathrm{mL}$ (Bunyatang et al., 2013). In this paper, partial inhibition was obtained using $0.11 \mathrm{mg}$ of putative HbPI inhibiting a maximum of $46.25 \%$ mycelium growth in three tested fungi after 4 days. Taken together; these results show that the purity of PI and the duration of treatment were the imperative and required factors in order to measure antifungal activity. 

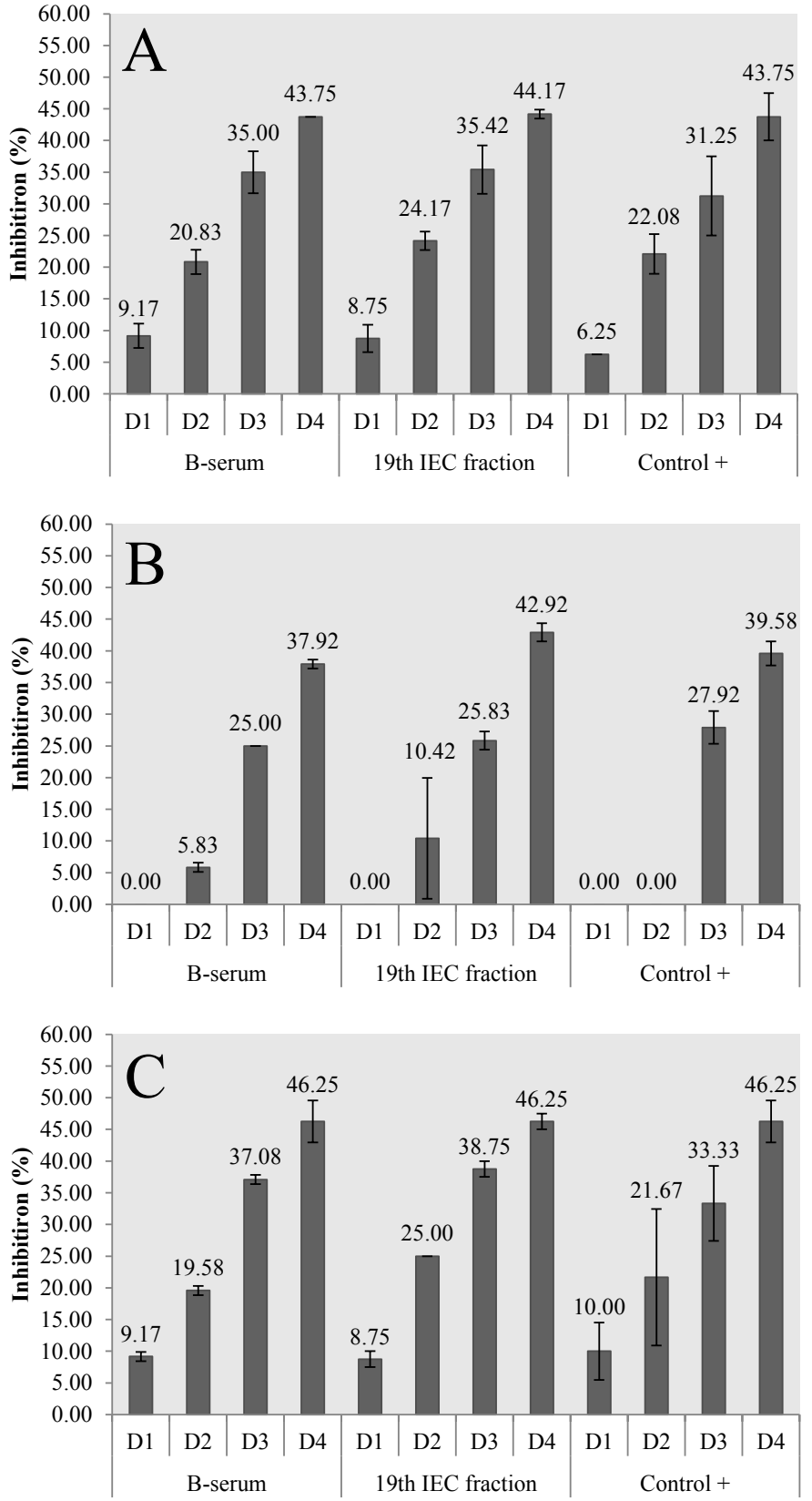

Figure 6. Profile of G. boninense (A), Sclerotium sp. (B), and R. lignosus (C) on in vitro growth inhibition against B-serum and IEC fraction during 4 days (D1-4). The pure $19^{\text {th }}$ IEC fraction was used as tested antifungal agent. Values are mean ratio of three biological replicates between the growth difference of untreated and treated fungi. Control+: cocktail protease inhibitor P8340. Control-: $\mathrm{H}_{2} \mathrm{O}$.

Gambar 6. Profil penghambatan dari G. boninense (A), Sclerotium sp.(B), dan R. lignosus (C) pada penghambatan pertumbuhan secara in vitro oleh serum B dan fraksi IEC selama 4 hari (D1-4). Fraksi murni IEC ke-19 digunakan sebagai agensia antifungi uji. Nilai adalah rerata nilai rasio dari perbedaan pertumbuhan jamur uji antara kontrol negatif tanpa perlakuan dan perlakuan sebanyak tiga ulangan biologis. Control+: cocktail protease inhibitor P8340. Control-: $\mathrm{H}_{2} \mathrm{O}$.

To estimate the economic potential of putative protease inhibitors from $H$. brasiliensis latex, the yield per latex sampling can be calculated. One liter of latex contained as much as $15-20 \mathrm{~mL}$ of B-serum. Based on this, two $\mathrm{mL}$ of $\mathrm{B}$-serum injected to ion exchange column can produce a maximum of 0.022 $\mathrm{g} / \mathrm{mL}$ fraction. In this work, if three fractions with each $3 \mathrm{~mL}$ volume are produced, the yield of protease inhibitors from B-serum is $3 \times 3 \times 0.022 \times(20 / 2)=$ $19.8 \mathrm{gr} / \mathrm{L}$ of latex. The production of 
putative protease inhibitor from fresh latex can be considered as an added value for latex normally used as the main raw material of rubber sheet. In conclusion, the local Indonesian protease inhibitor from latex has a high potential to be produced and utilized as antimicrobial compounds. In the future, the extraction of Hevea protease inhibitors from the waste of concentrated latex would be one solution of waste management in rubber industry, in addition to creating high value products (biofungicide).

\section{Conclusion}

Of the total 70 IEC fractions of protein extracted from the column, only 26 fractions showed measurable levels of protein. The concentration of Hevea putative protease inhibitors were ranged from 0.007 to $0.022 \mathrm{~m} / \mathrm{g}$ B-serum. Inhibitory activities against four protease enzymes (subtilisin A, trypsin, $\alpha$-chymotrypsin, and papain) showed the characteristic of Hevea putative PI as a serine and/or cysteine-type protease inhibitors. The result of SDSPAGE predicted the molecular weight of $21.5 \mathrm{kDa}$ for dominant proteins potentially Hevea protease inhibitors. In vitro bioassay test of antifungal activity for Hevea protease inhibitors showed reduced growth of $G$. boninense, Sclerotium sp., and $R$. lignosus.

\section{Acknowledgment}

This work was supported by SINas grant from the Indonesian Ministry of Research, Technology and Higher Education. The authors thank Ciomas Trial Station for latex sampling. We thank equally Marini and Anisa Zhafira for the experimental setup.

\section{References}

Al-Assadi SIH (2013). Extraction and purification of protease inhibitor from seeds of some plants and its antimicrobial activity. Int. J. Sci. and Tech. 8, 23-30.

Aoki Y, S Takahashi, D Takayama, Y Ogata, N Sakurai, H Suzuki, K Asawatreratanakul, D Wititsuwannakul, R Wititsuwannakul, D Shibata, T Koyama \& T Nakayama (2014). Identification of laticifer-specific genes and their promoter regions from a natural rubber producing plant Hevea brasiliensis. Plant Sci 225, 1-8.

Bangrak P \& W Chotigeat (2011). Molecular cloning and biochemical characterization of a novel cystatin from Hevea rubber latex. Plant Physiol Biochem 49, 244-50.

Bijina B, S Chellappan, SM Basheer, KK Elyas, AH Bahkali \& M Chandrasekaran (2011). Protease inhibitor from Moringa oleifera leaves: Isolation, purification, and characterization. Process Biochemistry 46, 2291-2300.

Boex-Fontvieille E, S Rustgi, S Reinbothe \& C Reinbothe (2015). A Kunitz-type protease inhibitor regulates programmed cell death during flower development in Arabidopsis thaliana. Journal of Experimental Botany 66, 6119-6135.

Bokma E, T Barends, AC Terwisscha van Scheltinga, BW Dijkstra \& JJ Beintema (2000). Enzyme kinetics of hevamine, a chitinase from the rubber tree Hevea brasiliensis. FEBS Letters 478, 119-122.

Bunyatang O, N Chirapongsatonkul, P Bangrak, R Henry \& N Churngchow (2016). Molecular cloning and characterization of a novel bifunctional $\alpha$-amylase/subtilisin inhibitor from Hevea brasiliensis. Plant Physiology and Biochemistry 101, 76-87.

Bunyatang $\mathrm{O}, \mathrm{N}$ Chirapongsatonkul \& $\mathrm{N}$ Churngchow (2013). Purification of a Protease Inhibitor from Hevea brasiliensis cell suspension and it's effect on the growth of Phytophthora palmivora. Journal of Plant Biochemistry and Biotechnolog, 22, 185-192.

Chaudhary NS, C Shee, A Islam, F Ahmad, D Yernool, P Kumar \& AK Sharma (2008). Purification and characterization of a trypsin inhibitor from Putranjiva roxburghii seeds. Phytochemistry 69, 2120-2126.

Chisholm ST, G Coaker, B Day \& BJ Staskawicz (2006). Host-microbe interactions: shaping the evolution of the plant immune response. Cell 124, 803-814.

Churngchow N, A Suntaro \& R Witttsuwannnakul (1995). $\beta$-1,3-glucanase isozymes from the latex of Hevea brasiliensis. Phytochemistry 39, 505509.

Chye M-L \& K-Y Cheung (1995). $\beta$-1,3-Glucanase is highly-expressed in laticifers of Hevea brasiliensis. Plant Molecular Biology 29, 397402.

Clément-Demange A, PM Priyadarshan, TT Thuy Hoa \& P Venkatachalam (2007). Hevea Rubber breeding and genetics. In Plant Breeding Reviews, John Wiley \& Sons, Inc. 177-283.

Menara Perkebunan 2016, 84 (2),76-87 
de Faÿ E \& JL Jacob (1989). Anatomical organization of the laticiferous system in the bark. In J. d'Auzac, J. L. Jacob \& H. Chrestin (ed) Physiology of Rubber Tree Latex. Florida, CRC Press Inc. p. 4-14.

Farady CJ \& CS Craik (2010). Mechanisms of macromolecular protease inhibitors. Chem Bio Chem, 11, 2341-2346.

Habib H \& KM Fazili (2007). Plant protease inhibitors: a defense strategy in plants. Biotechnology and Molecular Biology Review 2, 68-85.

Hartl M, AP Giri, H Kaur \& IT Baldwin (2011). The multiple functions of plant serine protease inhibitors: Defense against herbivores and beyond. Plant Signaling \& Behavior 6, 10091011.

Howe GA \& G Jander (2008). Plant immunity to insect herbivores. Annual Review of Plant Biology 59, 41-66.

Hushiarian R, NA Yusof \& SW Dutse (2013). Detection and control of Ganoderma boninense: strategies and perspectives. SpringerPlus 2, 555.

Islamov R, T Kustova \& A Ilin (2012). Inhibitors of serine proteinase - application in agriculture and medicine. In P. D. Ekinci (ed) Medicinal Chemistry and Drug Design, InTech.

Jacob J-L, J d'Auzac \& J-C Prévôt (1993). The composition of natural latex from Hevea brasiliensis. Clinical Reviews in Allergy 11,325337.

Jungbauer A \& R Hahn (2009). Chapter 22 ionexchange chromatography. In RB Richard \& P D Murray (ed) Methods in enzymology, Academic Press. p.349-371.

Kanokwiroon K, R Teanpaisan, D Wititsuwannakul, AB Hooper \& R Wititsuwannakul (2008). Antimicrobial activity of a protein purified from the latex of Hevea brasiliensis on oral microorganisms. Mycoses 51, 301-7.

Kim J-Y, S-C Park, I Hwang, H Cheong, J-W Nah, K-S Hahm \& Y Park (2009). Protease inhibitors from plants with antimicrobial activity. International Journal of Molecular Sciences 10, 2860-2872.

Malolo F-A, A Bissoue Nouga, A Kakam, K Franke, L Ngah, O Flausino, E Mpondo Mpondo, F NtieKang, J Ndom, V Bolzani \& L Wessjohann (2015). Protease-inhibiting, molecular modeling and antimicrobial activities of extracts and constituents from Helichrysum foetidum and
Helichrysum mechowianum (compositae). Chemistry Central Journal 9, 32.

Martin MN (1991). The latex of Hevea brasiliensis contains high levels of both chitinases and chitinases/lysozymes. Plant Physiology 95, 469476.

Mendoza-Blanco W \& JA Casaretto (2012). The serine protease inhibitors and plant-insect interaction. IDESIA 30, 121-126.

Misas-Villamil JC \& RAL van der Hoorn (2008). Enzyme-inhibitor interactions at the plantpathogen interface. Current Opinion in Plant Biology 11, 380-388.

Moir GFJ (1959). Ultracentrifugation and staining of Hevea Latex. Nature 184, 1626-1628.

Musor A, C Wilaiwan \& P Amornrat (2010). Cloning and characterization of protease inhibitor from latex of rubber tree (Hevea brasiliensis). KKU $\operatorname{Res}(G S)$ 8, 12-17.

Ogbebor NO, AT Adekunle, ON Eghafona \& AI Ogboghodo (2015) Biological control of Rigidoporus lignosus in Hevea brasiliensis in Nigeria. Fungal Biology 119, 1-6.

Omorusi VI (2012). Effects of white root rot disease on Hevea brasiliensis (Muell. Arg.)-challenges and control approach In: DNK Dhal (ed) InTech.

Paiva PM, EV Pontual, L Coelho \& TH Napoleão (2013). Protease inhibitors from plants: biotechnological insights with emphasis on their effects on microbial pathogens. Science Technology and Education 1,641-649

Parijs J, WF Broekaert, IJ Goldstein \& WJ Peumans (1991). Hevein: an antifungal protein from rubber-tree (Hevea brasiliensis) latex. Planta $183,258-264$.

Popovic M, U Andjelkovic, M Grosdanovic, I Aleksic \& M Gavrovic-Jankulovic (2013). In vitro antibacterial activity of cysteine protease inhibitor from Kiwifruit (Actinidia deliciosa). Indian Journal of Microbiology 53, 100-105.

Ryan CA (1990) Protease inhibitors in plants: genes for improving defenses against insects and pathogens. Annual Review of Phytopathology 28, 425-449.

Sabotič J, K Koruza, B Gabor, M Peterka, M Barut, J Kos \& J Brzin (2012). The value of fungal protease inhibitors in affinity chromatography. In Affinity Chromatography, In: DS Magdeldin (ed) InTech. 
Sack M, A Hofbauer, R Fischer \& E Stoger (2015). The increasing value of plant-made proteins. Current Opinion in Biotechnology 32, 163-170.

Shan LEI, C Li, F Chen, S Zhao \& G Xia (2008). A Bowman-Birk type protease inhibitor is involved in the tolerance to salt stress in wheat. Plant, Cell \& Environment 31, 1128-1137.

Siswanto (2012). Two-dimensional gel electrophoresis and immunoblotting for detection of antigenic proteins from natural rubber latex. Menara Perkebunan 80(1), 57-67.

Soependi IY \& Y Arianto (2014). Tree crop estate statistics of Indonesia: rubber 2013-2015 In: I. R. Nurbahar (ed). Jakarta, Directorate General of Estate Crops.

Sritanyarat W, G Pearce, WF Siems, CA Ryan, R Wititsuwannakul \& D Wititsuwannakul (2006). Isolation and characterization of isoinhibitors of the potato protease inhibitor I family from the latex of the rubber trees, Hevea brasiliensis. Phytochemistry 67, 1644-50.

Steppuhn A \& IT Baldwin (2007). Resistance management in a native plant: nicotine prevents herbivores from compensating for plant protease inhibitors. Ecology Letters 10, 499-511.
Suryanto D, RH Wibowo, EMB Siregar \& E Munir (2012). A possibility of chitinolytic bacteria utilization to control basal steam disease by Ganoderma boninense in oil palm seedling. African Journal Microbiology 6, 2053-2059.

van der Hoorn RAL (2008). Plant proteases: from phenotypes to molecular mechanisms. Annual Review of Plant Biology 59, 191-223.

Zhang X, S Liu \& T Takano (2008). Two cysteine proteinase inhibitors from Arabidopsis thaliana, AtCYSa and AtCYSb, increasing the salt, drought, oxidation and cold tolerance. Plant Molecular Biology 68, 131-143.

Zhirnov OP, HD Klenk \& PF Wright (2011a). Aprotinin and similar protease inhibitors as drugs against influenza. Antiviral Research 92, 27-36.

Zhirnov OP, TY Matrosovich, MN Matrosovich \& H-D Klenk (2011b). Aprotinin, a protease inhibitor, suppresses proteolytic activation of pandemic H1N1v influenza virus. Antiviral Chemistry and Chemotherapy 21, 169-174. 